\title{
SELF-ESTEEM, ADVERSITY QUOTIENT AND SELF-HANDICAPPING: WHICH ASPECTS ARE CORRELATED WITH ACHIEVEMENT GOALS?
}

\author{
Hasanuddin Jumareng ${ }^{1 *}$, Edi Setiawan ${ }^{2}$ \\ ${ }^{1}$ Universitas Halu Oleo, Indonesia \\ ${ }^{2}$ Universitas Suryakancana, Indonesia \\ *e-mail: hasanuddinjumareng@uho.ac.id
}

\begin{abstract}
Psychology is one of the potential factors to be successful in physical education learning at universities. However, it is still unknown that among self-esteem, adversity quotient, and self-handicapping has more correlation with achievement goals. This quantitative correlational study aims to investigate the correlation among self-esteem, adversity quotient, self-handicapping, and achievement goals. The participants of this study were 80 female students. These student were in the third or fourth years of the participating universities. The instruments to collect the data were self-esteem, adversity quotient, self-handicapping, and achievement goal questionnaires. In statistical analysis, SPSS version 25 was used to find bivariate correlation and regression with a significance level of .05 . The results show that self-esteem is positively correlated with adversity quotient, self-handicapping, and goal achievement. Then, the adversity quotient is positively correlated with self-handicapping and achievement goals. Meanwhile, self-handicapping has a negative correlation with achievement goals. To optimally achieve the goals in physical education classes, the aspects of self-esteem and adversity quotient should be correlated. However, self-esteem does not necessarily need to be correlated with self-handicapping. This study benefits the development of science, especially the field of psychology and physical education. The result of this study may be used to produce students with a high level of achievement goals in physical education learning at universities.
\end{abstract}

Keywords: self-esteem, adversity quotient, self-handicapping, achievement goal.

\section{SELF-ESTEEM, ADVERSITY QUOTIENT DAN SELF-HANDICAPPING: ASPEK MANA YANG BERKORELASI DENGAN ACHIEVEMENT GOAL?}

\begin{abstract}
Abstrak: Psikologi merupakan salah satu faktor yang berpotensi memengaruhi keberhasilan dalam proses pembelajaran pendidikan jasmani di tingkat universitas. Namun, di antara self-esteem, adversity quotient, self-handicapping belum diketahui faktor-faktor mana yang lebih berkorelasi dengan achievement goal. Tujuan penelitian kuantitatif korelasional ini adalah untuk menyelidiki hubungan antara self-esteem, adversity quotient, self-handicapping dengan achievement goal. Subjek penelitian adalah 80 mahasiswa perempuan. Mereka adalah mahasiswa tingkat III dan IV. Instrumen yang digunakan adalah self-esteem questionnaire, adversity quotient questionnaire, self-handicapping questionnaire dan achievement goal questionnaire. Dalam analisis statistik SPSS versi 25 digunakan untuk mengetahui korelasi bivariat dan analisis regresi dengan taraf signifikansi 0,05 . Hasil penelitian menunjukkan bahwa self-esteem berhubungan positif dengan adversity quotient, self-handicapping, dan achievement goal. Adversity quotient berkorelasi positif dengan self-handicapping dan achievement goal. Sedangkan self-handicapping berkorelasi negatif dengan achievement goal. Untuk memperoleh achievement goal yang optimal di kelas pendidikan jasmani diperlukan adanya keterkaitan dari aspek self-esteem dan adversity quotient. Namun, achievement goal tidak perlu berkaitan dengan self-handicapping. Penelitian ini memberikan manfaat bagi pengembangan ilmu pengetahuan, khususnya di bidang psikologi dan pendidikan jasmani. Nantinya penelitian ini berpotensi menciptakan mahasiswa dengan achievement goal yang tinggi dalam proses pembelajaran pendidikan jasmani di tingkat universitas.
\end{abstract}

Kata Kunci: self-esteem, adversity quotient, self-handicapping, achievement goal. 


\section{INTRODUCTION}

Achievement goal is the important topic and becomes a factor that must be achieved optimally in a lesson (Lüftenegger, Klug, Harrer, Langer, Spiel, \& Schober, 2016). To achievement goal as expected, students are required to prove their competence among other students by performing the best possible movement tasks, so as to get the best results (Erturan, McBride, \& Agbuga, 2020). Essentially, the achievement goal theory is to determine whether students can perform an academic task well or not (Elliot, Murayama, \& Pekrun, 2011; Awofala, Arigbabu, Fatade, \& Awofala, 2013). Ferradás, Freire, Núñez, \& Regueiro (2019) stated that central to achievement goal theory is the definition of competence; that is, the standard or referent used to determine if an individual is doing well or poorly. Achievement goal has become a parameter to see the extent to which students participate developing their abilities in the physical education (PE) learning process (Proios, 2020). Several previous studies have conducted research on achievement goal in the context of physical activity and sports (Baghurst, Tapps, \& Kensinger, 2015; Ingrell, Johnson, \& Ivarsson, 2020), and in the past four decades, researchers have theoretically and empirically examined achievement goal orientations to understand students' motivation process in both educational and physical activity (Shen, Lee, Chen, \& Zhang, 2020), but it is rarely in the context of PE class. Therefore it is important to examine achievement goal in the context of PE and what factors are related to achievement goal.

Self-esteem has been claimed to be one of the factors related to achievement goal (Rahmani, 2011). Self-esteem has a definition as a person's feeling that reflects an assessment of himself, such as being proud and feeling he is great compared to others (Liu \& Xin, 2015; Liu, Wu, \& Ming, 2015; Pereira, Lopes, Gonçalves, \& Vasconcelos-Raposo, 2017; Schreiber, Agomate \& Oddi, 2017), or it can be interpreted as a feeling to judge the extent to which someone appreciates (Harter, 2015). According to Cheng \& Law (2015), self-esteem is a psychological factor that has an important position for students to live their daily lives and can have the potential to determine failure or success in achievement goal in lectures (Karaday \& İlker, 2018). High levels of self-esteem are generally more proud, great and satisfied with their abilities (Moksnes \& Espnes, 2013; Sowislo \& Orth, 2013). Conversely, low self-esteem is associated with various negative outcomes, such as the increase of drug abuse (Fisher, Fisher, Arsenault, Jacob, \& Barnes-Najor, 2020), delinquent behavior so it tends to produce depression, mental weakness, lack of self-confidence (Rubeli, Oswald, Conzelmann, Schmid, Valkanover, \& Schmidt, 2020).

In addition, previous studies found that self-esteem in male students was higher than in female not only during adolescence (Moksnes \& Espnes, 2013), but also during adulthood (Bleidorn, Arslan, Denissen, Rentfrow, Gebauer, Potter, \& Gosling, 2016). Then other studies found that students' self-esteem was positively associated with mastery goals and performanceapproach goals and negatively associated with performance goal (Chen, Sun, \& Wang, 2018). Soto-Sanz, Piqueras, Rodríguez-Marín, Pérez-Vázquez, Rodríguez-Jiménez, Castellví, Miranda-Mendizábal, Parés-Badell, Almenara, Blasco (2019) explained that students with low self-esteem had the inclination to believe that intelligence is a fixed and immutable trait while those with high self-esteem believed perseverance and persistence can help them obtain their goals.

The achievement goal level is also thought to have relevance to other psychological factors, namely the adversity quotient that is defined as intelligence in facing difficulties, obstacles or problems (Matore, Rahman, Idris, Khairani, \& Al Hapiz, 2020) in the PE learning process. Adversity quotient helps students to increase their potential that includes various components such as performance, motivation, self-confidence, self-direction, fighting spirit, creativity, productivity (Setiawan, Juliantine, Komarudin, 2017). Previous studies showed that the adversity quotient dimension has many positive results in its relevance to student academic performance and productivity in educational institutions (de Ridder, LensveltMulders, Finkenauer, Stok, \& Baumeister, 2012; Duckworth, Quinn, \& Tsukayama, 2013).

The next psychological factor that is thought to have relevance to a achievement goal is self- handicapping. The term of selfhandicapping is defined as the ability to show or create reasons (e.g. illness, injury, task context) 
(Coudevylle, Gernigon, \& Ginis, 2011), and other behaviors with the aim of making poor performance understandable by other students (Ferradás, Freire, Núñez, Piñeiro, \& Rosário, 2017). Self-handicapping can be a strategy for students to hide their inability to achieve goals optimally. By adopting a self-handicapping strategy, student self-esteem will be maintained and not be viewed badly by other students (Finez \& Sherman, 2012). For example, students claim that the test results are bad because they study late at night before the exam, or bad test results, because students are annoyed by their friends before taking the test, for these reasons students can save their self-esteem or student sabotages her or his own probabilities of success by creating an obstacle, real or fictitious, that serves as an alibi against an expected failure (Ferradás et al., 2019). But if he performs well, he may infer that he is intelligent or has ability because he succeeds in the exam without studying (Y1ldirım \& Demir, 2020).

Previous studies have reported that selfhandicapping has relevance to achievement goal (Schwinger \& Stiensmeier-pelster, 2011). However, if for long term self-handicapping cause mental and physical damage to students. Longitudinal study found that self-handicapping can cause a decrease in health and wellbeing, lower intrinsic motivation, and trigger negative emotions (Zuckerman \& Tsai, 2005; Chen et al., 2018). Yavuzer (2015) reported that self-handicapping tendency is associated with higher levels of cognitive distortion (e.g. self-blame, hopelessness). Several studies claimed that academic self-handicapping is associated with underachievement among gifted students (Mofield \& Peters, 2019; Snyder \& Linnenbrink-Garcia, 2013; Snyder, Malin, Dent, \& Linnenbrink-Garcia, 2014; Alodat, Ghazal \& Al-Hamouri, 2020).

Although self-esteem, adversity quotient and self-handicapping are claimed to have benefits with achievement goals, however there is still a gap from previous research. For example, the first gap has a negative correlation between self-esteem and achievement goals for girls (Asakereh \& Yousofi, 2018; Ahmed, Ho, van Niekerk, Morris, Elayaraja, Lee, \& Randles, 2017; Ferradás et al., 2019), the second gap shows that adversity quotient does not have a significant correlation with academic performance (Yazon \& Ang-Manaig, 2019), the third gap there is no correlation between self-handicapping and achievement goals (Urdan, 2004; Chen et al., 2018). Therefore, it is important to further investigate these three aspects.

Several previous studies have examined the relationship between self-esteem, achievement goals and academic achievement among the primary school students (Rahmani, 2011), global self-esteem, goal achievement orientations and self-determined behavioural regulations in a physical education setting (Hein \& Hagger, 2007), self-handicapping among university students: the role of procrastination, test anxiety, self-esteem, and self-compassion (Y1ldırım \& Demir, 2020), self-esteem, achievement goals, and self- handicapping in college physical education (Chen et al., 2018), self-esteem, self-confidence, anxiety and claimed self-handicapping: A mediational analysis (Coudevylle et al., 2011), associations between profiles of self-esteem and achievement goals and the protection of self-worth in university students (Ferradás et al., 2019), however no previous studies were reported about exploring correlation between self-esteem, adversity quotient and self-handicapping with achievement goal in the context of PE at the university level. In addition, previous research has only focused on examining the three aspects separately, so it is not accurately known which aspects have a correlation with achievement goals.

The purpose of this study was to exploring the correlation between self-esteem, adversity quotient, self-handicapping with achievement goal. The importance of the current study lies in the fact that it aims to exploring the correlation between self-esteem, adversity quotient and self-handicapping with achievement goal in the context of PE learning at the university level.

\section{METHODS}

This research is quantitative with correlational research methods. Correlational studies investigate possible relationships between two or more variables. However, correlational research is different from experimental research, because in correlational research there is no manipulation of variables, correlational research is sometimes referred as a form of descriptive research because it describes the relationship 
that exists between each variable.

\section{Subjects}

The subjects in this study were students (female) in third and fourth level in faculty physical education, health and recreation from the university where the author reside. The first one is a public university from Sulawesi $(n=$ 40 ) and the second one is a private university from West Java $(n=40)$, both in Indonesia. All subjects were asked to sign a letter of consent to participate in this research, but after obtaining permission from parents and the University. The sampling technique used was purposive sampling, with the criteria only to select female students at third and fourth level. The reason for choosing level three and four as the subject of this study, because they have basic knowledge of sports psychology. The characteristics of the subject can be seen in Table 1 .

Table 1. The Characteristics of Subject

\begin{tabular}{cccc}
\hline $\boldsymbol{N}$ & $\begin{array}{c}\text { Age } \\
\text { (year) }\end{array}$ & $\begin{array}{c}\text { Height } \\
\text { (cm) }\end{array}$ & $\begin{array}{c}\text { Weight } \\
\text { (kg) }\end{array}$ \\
\hline 80 & $19.7 \pm 1.01$ & $1.68 \pm 1.73$ & $59.97 \pm 4.20$
\end{tabular}

The value can be presented as mean \pm deviation standard

\section{Instrument}

\section{Self-Esteem}

Instruments for measuring self-esteem aspect can use the Self-Esteem Questionnaire (SEQ) (Rubeli et al., 2020). Based on previous studies, this instrument has 10 questions (Hein \& Hagger, 2007). However, researchers have modified the question items to fit the context of physical education learning at the university level, such as "I can do a task better than others". To answer this instrument, you can use a Likert scale starting from a value of 1 that means strongly disagrees, 2 disagrees, 3 disagrees, 4 agrees, and a value of 5 strongly agrees. After the SEQ instrument test results, the validity level was .93 and the reliability was .97 .

\section{Adversity Quotient}

The instrument for measuring the adversity quotient aspect of students is by using the Adversity Quotient Questionnaire (AQQ) with 4 indicators, namely Control, Origin and Ownership, Reach, Endurance and ten questions (Setiawan et al., 2017). To answer this instrument, you may use a Likert scale starting from a value of 1 strongly disagrees, 2 disagrees, 3 disagrees, 4 agrees, and a value of 5 strongly agrees. After the AQQ instrument test results, the validity level was .89 and the reliability was .92 .

\section{Self-Handicapping}

Instruments for measuring the selfhandicapping aspects of students can use the Self-Handicapping Scale (SHS) (Török, Szabó, $\&$ Tóth, 2018), with 6 question items. However, the researcher has modified it into 10 questions and adjusted it to the context of physical education learning at the university level, such as giving the excuse "I got a bad test result, because I played futsal late at night, before the exam". To answer this instrument, you can use a Likert scale starting from value 1 very like me, 2 like me, 3 hesitating, 4 not like me, and a value of 5 is very unlike me. After the results of the instrument test, the validity level was .70 and the reliability was .89 .

\section{Achievement Goal}

Instruments for measuring aspects of achievement goal in students can use the Achievement Goal Questionnaire (AGQ) from Elliot \& Church that consists of three indicators, namely mastery, performance approach and performance avoidance. Based on the results of the upstream study, this instrument has a validity level (.76-.84) and for reliability (.77-.91) (Vílchez \& Ruiz, 2016). In the previous study, AGQ had 18 question items, such as mastery goals (I want to learn as much as possible), performance approach (my results in physical education were better than other students), performance avoidance (my goal was to avoid poor performance) (Chen et al., 2018). However, in this study, the researcher will try to develop the AGQ instrument into 20 question items tailored to physical education learning at the university level. To answer this instrument, you can use a Likert scale starting from a value of 1 strongly disagrees, 2 disagrees, 3 disagrees, 4 agrees, and a value of 5 strongly agrees. After the test results of the AGQ instrument, the validity level was .83 and the reliability was .86 .

\section{Research Procedure}

This research has received permission from the two universities committee with number E 19/12/2020 and get approval from the 
parents of subjects. In addition, this study has followed the Ethics guidelines from the World Medical Association (Helsinki Declaration). All subjects were given 40 minutes to fill in the self-esteem instrument, adversity quotient, self-handicapping with achievement goal in their respective homes which was supervised by researchers through google meet. After filling out the questionnaire the subject must send the file via email. Then the questionnaire file will be examined by a researcher and two experts in sports psychology.

\section{Statistics Analysis}

Data obtained from the results of filling out the questionnaire and then the data will be processed using SPSS version 25 . The analysis was carried out using SPSS to find the normality test (Shapiro-Wilk). Pearson's Correlation was used to assess the relationships between selfesteem, adversity quotient, self-handicapping with achievement goal (Proios, 2020). A multiple regression analysis (Asakereh \& Yousofi, 2018) was run to examine the strongest predicator of self-esteem, adversity quotient, self-handicapping with achievement goal. The significance level used was .05.

\section{RESULTS AND DISCUSSION Results}

From the results of data normality test, it can be seen that the self-esteem variable has ( $p$
$=.855)$. While the adversity quotient variable ( $p$ $=.677)$, for the self-handicapping variable $(p=$ $.304)$ and achievement goal $(p=.648)$, thus it can be interpreted that all data were normally distributed. Table 2 shows descriptive statistics and Table 3 shows that self-esteem was positively correlated with adversity quotient $(r=.700, p<$ $.05)$, self-handicapping $(r=.850, p<.05)$, and achievement goal $(r=.845, P<.05)$. Adversity quotient were positively correlated with selfhandicapping $(r=.650, p<.05)$ and achievement goal $(r=.790, p<.05)$. Self-handicapping was negatively correlated with achievement goal $(r$ $=-.160, p>.05$ ). Table 4 shows the results of the regression analysis which shows that selfesteem $(\beta=.205 ; p<.05)$ and adversity quotient $(\beta=.157 ; p<.05)$ have a high correlation with goal achievement, but self-handicapping has a low correlation $(\beta=.-413 ; p>.05)$.

Table 2. Descriptive Statistics of SelfEsteem, Adversity Quotient, SelfHandicapping with Achievement Goal

\begin{tabular}{|c|c|c|c|c|}
\hline No. & Variable & $\boldsymbol{N}$ & Mean & $S D$ \\
\hline 1. & Self-esteem & 80 & 33.15 & 5.47 \\
\hline 2. & Adversity quotient & 80 & 29.45 & 11.06 \\
\hline 3. & Self-handicapping & 80 & 27.85 & 8.95 \\
\hline 4. & Achievement goal & 80 & 32.21 & 5.17 \\
\hline
\end{tabular}

Table 3. Correlations Self-Esteem, Adversity Quotient, Self Handicapping with Achievement Goal

\begin{tabular}{llllll}
\hline Variables & $\begin{array}{l}\text { C. Pearson } \\
\text { p-value }\end{array}$ & $\mathbf{1}$ & $\mathbf{2}$ & $\mathbf{3}$ & $\mathbf{4}$ \\
\hline Self-esteem & C. Pearson & $.700^{* *}$ & & & \\
Adversity quotient & $p$-value & .000 & - & & \\
& C. Pearson & $.850^{* *}$ & $.650^{* *}$ & & \\
Self-handicapping & $p$-value & .001 & .009 & - & \\
& C. Pearson & $.845^{* *}$ & $.790^{* *}$ & -.160 & \\
Achievement goal & $p$-value & .000 & .003 & .182 & - \\
& &
\end{tabular}

Note: ${ }^{* *}$. Correlation is significant at the .5 level (2-tailed)

Table 4. The Regression Coefficients

\begin{tabular}{|c|c|c|c|c|c|}
\hline \multirow{2}{*}{ Model } & \multicolumn{2}{|c|}{$\begin{array}{c}\text { Unstandardized } \\
\text { Coefficients }\end{array}$} & \multirow{2}{*}{$\begin{array}{c}\begin{array}{c}\text { Standardized } \\
\text { Coefficients }\end{array} \\
\text { Beta } \\
\end{array}$} & \multirow{2}{*}{$t$} & \multirow{2}{*}{$p$} \\
\hline & $\boldsymbol{B}$ & Std. Error & & & \\
\hline (Constant) & 2.747 & .010 & & 3.361 & .000 \\
\hline Self-esteem & .087 & .021 & .205 & 3.660 & .002 \\
\hline Adversity quotient & .074 & .032 & .157 & 3.597 & .011 \\
\hline Self-handicapping & -.156 & .116 & -.413 & -1.817 & .326 \\
\hline
\end{tabular}

Note: Dependent variable: Achievement goal 


\section{Discussion}

This study aimed to analyze how the correlation between self-esteem, adversity quotient, self-handicapping with achievement goal in physical education courses at the university level. The results of this study confirm that all hypotheses are significant.

We confirm that the results of this study showed that there is a high correlation between self-esteem variables and achievement goal. Self-esteem is one of the psychological aspects that is very important for students to undergo physical education learning successfully, because high self-esteem will trigger motivation and self-confidence in learning. With increased motivation and self-confidence it will lead to more optimal achievement goal ( $\mathrm{Li}, \mathrm{Xu}, \& \mathrm{Liu}$, 2014). The results of this study are in line with previous studies which reported that students with high self-esteem were able to evaluate their own strengths and weaknesses, and they were more confident when handling difficult mobile tasks in the physical education learning process (Coudevylle et al., 2011). Several previous studies claim that high self-esteem is able to increase their abilities faster than other students, because they tend to prefer to challenge difficult learning tasks, and try to persist until the task can be completed (Chen et al., 2018). However, if students with low self-esteem are less likely to be motivated to participate in physical activities and sports (Hein \& Hagger, 2007). In addition, they lack self-confidence and feel unable to perform a task. They even lack selfrespect, and exaggerate the difficulties faced in physical education and sports lessons (Finez \& Sherman, 2012). Rahmani, (2011) research results, indicate that self-esteem is an important and effective factor to help children be more successful in achievement goal and achieving academic achievement. Thus, it can be implied that to obtain optimal achievement goal in learning physical education, a student must have a high level of self-esteem.

The next finding in this study is that there is a high positive correlation between the adversity quotient variable and the achievement goal. Basically the adversity quotient is an ability to use one's intelligence in facing difficulties, because in a high adversity quotient there are several supporting components, such as selfesteem, motivation, fighting spirit, creativity, positive attitude, optimism and emotional stability (Saeid \& Eslaminejad, 2016). Another study shows that in the adversity quotient there are several components, such as fighting power and persistence (Matore, Khairani, \& Razak, 2015). All of these components are important for students in facing the change in the learning system that is increasingly challenging and difficult, especially in the current Covid-19 era which often causes disappointment and frustration for most students. Previous studies also support the results of this study that the importance of the adversity quotient dimension for a student to achievement goal and achieve academic achievement (Mwivanda \& Kingi, 2019).

Other findings in this study shows that student with a high adversity quotient level view challenges as temporary and they exert control over these challenges. In contrast, student with low adversity quotient believe that challenges are entirely their own fault. In other words, these individuals view these challenges as out of their hands and blame themselves for the adversity experienced. In short, adversity quotient is important feature that drives and maintains excellence, because undergraduates with high adversity quotient will see academic challenges such as difficulty in obtaining materials and lecturer expectations that can be overcame (Khairani \& Abdullah, 2018). Thus, it can be implied that if students have an adversity quotient, then they have the ability to refrain from attacking and intelligence in dealing with all problems or difficulties during learning, so that academic achievement goal is far more optimal.

In this study also found that there was no correlation between self-handicapping variables and achievement goal. Self-handicapping is a person's ability to argue that a poor performance result is due to something happening to him, such as giving reasons for being sick, injured or having a problem (Coudevylle, Boulley-Escriva, Finez, Eugène, \& Robin, 2020). All of these reasons are used as a strategy to cover achievement goal that is not achieved maximally (Schwinger \& Stiensmeier-pelster, 2011), or protection of selfesteem, because they are reluctant to accept the possibility of negative evaluation of processes and results from others (Coudevylle, Sinnapah, Charles-Charlery, Baillot, \& Hue, 2015). The 
academic scope, especially physical education, often causes the emergence of self-handicapping behavior among students. Students are faced with various mobility tests that require them to compete for high achievement.

The test results of the ability to move are not only personal information for the student concerned, but also for other students and lecturers (Ferradás et al., 2019), so that students often use self-handicapping strategies to cover up the results of poor mobility tests, so as not to be bullied or belittled by other students. In addition, self-handicapping can be used as a strategy so as not to be blamed by teammates, when there is a failure or defeat. In previous research in the context of sports, selfhandicapping was associated with decreased performance (Coudevylle et al., 2020), these results are consistent with this study which shows there is no correlation between selfhandicapping and achievement goal. Thus, to minimize self-handicapping behavior among students in PE lectures at the University level, therefore it is necessary to increase the level of self-esteem, adversity quotient (Chen et al., 2018) so that achievement goal can be obtained maximally.

Meanwhile, according to Ferradás et al. (2019), it is important for an educator to adopt several guidelines aimed at preventing the use of self-handicapping in an academic environment: for example agree with the students' learning objectives, activities, or projects to be developed, evaluation criteria, and deadlines, divide the academic tasks and the study into smaller steps and encourage the students to elaborate action plans to carry them out, encourage students to analyze the causes of their mistakes and provide them with additional opportunities to pass exams or improve academic work, emphasize the importance of improving one's performance and not competing with others, as well as making explicit the positive qualities of each student, provide students with evaluative feedback based on the degree of effort expended and the appropriate/inadequate use of work strategies (i.e., controllable factors).

\section{CONCLUSIONS}

The present study provides strong evidence for the usefulness and importance of self-esteem and adversity quotient on achievement goals for students in the PE learning process at the university level, but not for self-handicapping. In this study, there are still limitations, namely the subjects used are relatively few and only come from two tertiary institutions in Indonesia with different regions. Nevertheless, the implication of this research is that it can provide information and benefits for lecturers, psychologists, teachers, and trainers about the importance of self-esteem and adversity quotient with goal achievement, with this information they can more attention and develop these two aspects so that the achievement goals is more optimal for student.

Further research needs to be done by adding male and female research subjects from several universities in Indonesia, because men and women must have differences in selfesteem and adversity quotient on achievement goals. More importantly, future researchers may need to investigate the main factors that cause self-handicapping to have no correlation with achievement goals. In addition, future research should do the filling out of questionnaires not through Google meet, but directly in the university environment supervised by researchers.

\section{REFERENCES}

Ahmed, M. D., Ho, W. K. Y., van Niekerk, R. L., Morris, T., Elayaraja, M., Lee, K.-C., \& Randles, E. (2017). The self-esteem, goal orientation, and health-related physical fitness of active and inactive adolescent students. Cogent Psychology, 4(1), 1-14. https://doi.org/10.1080/23311908.2017.1 $\underline{331602 .}$.

Alodat, A. M., Ghazal, M. M., \& Al-Hamouri, F. A. (2020). Perfectionism and academic self-handicapping among gifted students: An explanatory model. International Journal of Educational Psychology, 9(2), 195-222. https://doi.org/10.17583/ ijep.2020.4426.

Asakereh, A., \& Yousofi, N. (2018). Reflective thinking, self-efficacy, self-esteem and academic achievement of Iranian EFL students. International Journal of Educational Psychology, 7(1), 68-89. https://doi.org/10.17583/ijep.2018.2896.

Awofala, A. O. A., Arigbabu, A. A., Fatade, A. 
O., \& Awofala, A. A. (2013). Examining the psychometric properties of the achievement goals questionnaire among nigerian preservice mathematics and science teachers. Electronic Journal of Research in Educational Psychology, 11(3), 743-770. https://doi.org/10.14204/ ejrep.31.13037.

Baghurst, T., Tapps, T., \& Kensinger, W. (2015). Setting goals for achievement in Physical education settings. Strategies, 28(1), 27 33. https://doi.org/10.1080/08924562.201 4.980876.

Bleidorn, W., Arslan, R. C., Denissen, J. J. A., Rentfrow, P. J., Gebauer, J. E., Potter, J., \& Gosling, S. D. (2016). Age and gender differences in self-esteem-A crosscultural window. Journal of Personality and Social Psychology, 111(3), 396-410. https://doi.org/10.1037/pspp0000078.

Chen, Z., Sun, K., \& Wang, K. (2018). Self-esteem, achievement goals, and self-handicapping in college Physical education. Psychological Reports, 121(4), 690-704. https://doi. org/10.1177/0033294117735333.

Cheng, S. K., \& Law, M. Y. (2015). Mediating effect of self-esteem in the predictive relationship of personality and academic self-handicapping. American Journal of Applied Psychology, 4(3), 51-57. https:// doi.org/10.11648/j.ajap.s.2015040301.19.

Coudevylle, G. R., Boulley-Escriva, G., Finez, L., Eugène, K., \& Robin, N. (2020). An experimental investigation of claimed self-handicapping strategies across motivational climates based on achievement goal and self-determination theories. Educational Psychology, 40(8), 1002-1021. https://doi.org/10.1080/0144 $\underline{3410.2020 .1746237 .}$.

Coudevylle, G. R., Gernigon, C., \& Ginis, K. A. M. (2011). Self-esteem, self-confidence, anxiety and claimed self-handicapping: A mediational analysis. Psychology of Sport and Exercise, 12(6), 670-675. https://doi. org/10.1016/j.psychsport.2011.05.008.
Coudevylle., G. R., Sinnapah, S., CharlesCharlery, C., Baillot, M., \& Hue, O. (2015). Impact of motivational climates on claimed self-handicapping strategies: Illustration in tropical environment. Journal of Applied Sport Psychology, 27(4), 384-397. https://doi.org/10.1080/1 $\underline{0413200.2015 .1014975 .}$.

de Ridder, D. T. D., Lensvelt-Mulders, G., Finkenauer, C., Stok, F. M., \& Baumeister, R. F. (2012). Taking stock of self-control: A meta-analysis of how trait self-control relates to a wide range of behaviors. Personality and Social Psychology Review, 16(1), 76-99. https:// doi.org/10.1177/1088868311418749.

Duckworth, A. L., Quinn, P. D., \& Tsukayama, E. (2012). What no child left behind leaves behind: The roles of IQ and self-control in predicting standardized achievement test scores and report card grades. Journal of Educational Psychology, 104(2), 439451. https://doi.org/10.1037/a0026280.

Elliot, A. J., Murayama, K., \& Pekrun, R. (2011). A $3 \times 2$ achievement goal model. Journal of Educational Psychology, 103(3), 632648. https://doi.org/10.1037/a0023952.

Erturan, G., McBride, R., \& Agbuga, B. (2020). Self-regulation and self-efficacy as mediators of achievement goals and leisure time physical activity: a proposed model. Pedagogy of Physical Culture and Sports, 24(1), 12-20. https://doi.org/10.15 $\underline{561 / 18189172.2020 .0102 .}$.

Ferradás, M. D. M., Freire, C., Núñez, J. C., Piñeiro, I., \& Rosário, P. (2017). Motivational profiles in university students. Its relationship with selfhandicapping and defensive pessimism strategies. Learning and Individual Differences, 56, 128-135. https://doi. org/10.1016/j.lindif.2016.10.018.

Ferradás, M. D. M., Freire, C., Núñez, J. C., \& Regueiro, B. (2019). Associations between profiles of self-esteem and achievement goals and the protection of self-worth in university students International Journal of Environmental Research and 
Public Health, 16(12), 1-20. https://doi. org/10.3390/ijerph16122218.

Finez, L., \& Sherman, D. K. (2012). Train in vain: The role of the self in claimed selfhandicapping strategies. Journal of Sport and Exercise Psychology, 34(5), 600-620. https://doi.org/10.1123/jsep.34.5.600.

Fisher, A. E., Fisher, S., Arsenault, C., Jacob, R., \& Barnes-Najor, J. (2020). The moderating role of ethnic identity on the relationship between school climate and self- esteem for African American adolescents. School Psychology Review, 49(3), 291-305. https://doi.org/10.1080/2 372966X.2020.1760690.

Harter, S. (2015). Self-development in childhood and adolescence. In J. Wright. (Ed.). International encyclopedia of the social $\&$ behavioral sciences ( $2^{\text {nd }}$ ed, Vol. 21). Oxford: Elsevier, pp. 492-497. https://doi. org/10.1016/B978-0-08-097086-8.23019$\underline{5}$.

Hein, V., \& Hagger, M. S. (2007). Global selfesteem, goal achievement orientations, and self-determined behavioural regulations in a physical education setting. Journal of Sports Sciences, 25(2), 149-159. https:// doi.org/10.1080/02640410600598315.

Ingrell, J., Johnson, U., \& Ivarsson, A. (2020). Achievement goals in youth sport and the influence of coaches, peers, and parents: A longitudinal study. Journal of Human Sport and Exercise, 15(3), 570-590. https://doi. org/10.14198/jhse.2020.153.09.

Karaday, E., \& İlker, G. E. (2018). Predictors of self-esteem in Physical education: Selfdetermination perspective. International Journal of Psychology and Educational Studies, 5(2), 39-47. http://www.ijpes. com/index.php/ijpes/article/view/55.

Khairani, A. Z., \& Abdullah, S. M. S. (2018). Relationship between adversity quotient and academic well-being among Malaysian undergraduates. Asian Journal of Scientific Research, 11(1), 51-55. https://doi.org/10.3923/ajsr.2018.51.55.
Li, Y., Xu, Z., \& Liu, S. (2014). Physical activity, self-esteem, and mental health in students from ethnic minorities attending colleges in China. Social Behavior and Personality, 42(4), 529-537. https://doi.org/10.2224/ sbp.2014.42.4.529.

Liu, D., \& Xin, Z. (2015). Birth cohort and age changes in the self-esteem of Chinese adolescents: A cross-temporal metaanalysis, 1996-2009. Journal of Research on Adolescence, 25(2), 366-376. https:// doi.org/10.1111/jora.12134.

Liu, M., Wu, L., \& Ming, Q. (2015). How does physical activity intervention improve self-esteem and self-concept in children and adolescents? Evidence from a metaanalysis. PLoS ONE, 10(8), 1-17. https:// doi.org/10.1371/journal.pone.0134804.

Lüftenegger, M., Klug, J., Harrer, K., Langer, M., Spiel, C., \& Schober, B. (2016). Students' achievement goals, learningrelated emotions and academic achievement. Frontiers in Psychology, 7(603), 1-10. https://doi.org/10.3389/ fpsyg.2016.00603.

Matore, M. E. E. M., Khairani, A. Z., \& Razak, N. A. (2015). The influence of AQ on the academic achievement among Malaysian polytechnic students. International Education Studies, 8(6), 69-74. https:// doi.org/10.5539/ies.v8n6p69.

Matore, M. E. E. M., Rahman, N. A., Idris, H., Khairani, A. Z., \& Al Hapiz, N. M. (2020). Is adversity quotient (AQ) able to predict the academic performance of polytechnic students? Journal of Critical Reviews, 7(3), 393-398. https://doi.org/10.31838/ JCR.07.03.75.

Mofield, E. L., \& Peters, M. P. (2019). Understanding underachievement: mindset, perfectionism, and achievement attitudes among gifted students. Journal for the Education of the Gifted, 42(2), 107-134. https://doi. org/10.1177/0162353219836737.

Moksnes, U. K., \& Espnes, G. A. (2013). Selfesteem and life satisfaction in adolescents- 
gender and age as potential moderators. Quality of Life Research, 22(10), 29212928. https://doi.org/10.1007/s11136013-0427-4.

Mwivanda, M., \& Kingi, P. M. (2019). Teachers' adversity quotient dimension of control and students academic performance in secondary schools in Kenya. Journal of Education and Training, 6(1), 83-94. https://doi.org/10.5296/jet.v6i1.14373.

Pereira, H. P., Lopes, D. G., Gonçalves, M. C., \& Vasconcelos-Raposo, e. J. J. (2017). Psychological well-being and self-esteem among university students. American Journal of Exercise and Sports Psychology, 12(2), 297-305. https://www. riped-online.com/abstract/psychologicalwellbeing-and-selfesteem-amonguniversity-students-18905.html.

Proios, I. (2020). Influence of volitional competencies on achievement goals of people with physical disability in physical activity settings. Physical Culture and Sport, Studies and Research, 85(1), 30-39. https://doi.org/10.2478/pcssr-2020-0004.

Rahmani, P. (2011). The relationship between self-esteem, achievement goals and academic achievement among the primary school students. Procedia - Social and Behavioral Sciences, 29, 803-808. https:// doi.org/10.1016/j.sbspro.2011.11.308.

Rubeli, B., Oswald, E., Conzelmann, A., Schmid, J., Valkanover, S., \& Schmidt, M. (2020). Promoting schoolchildren's self-esteem in physical education: testing the effectiveness of a five-month teacher training. Physical Education and Sport Pedagogy, 25(4), 346-360. https://doi.org /10.1080/17408989.2020.1712348.

Saeid, N., \& Eslaminejad, T. (2016). Relationship between student's self-directed-learning readiness and academic self-efficacy and achievement motivation in students. International Education Studies, 10(1), 225-232. https://doi.org/10.5539/ies. v10n1p225.

Schreiber, D., Agomate, J.-C., \& Oddi, B.
(2017). The impact of demographic influences on academic performance and student satisfaction with learning as related to self-esteem, self- efficacy and cultural adaptability within the context of the military. International Journal of Learning, Teaching and Educational Research, 16(4), 67-90. https://www.ijlter. org/index.php/ijlter/article/view/903.

Schwinger, M., \& Stiensmeier-Pelster, J. (2011). Performance-approach and performance: Avoidance classroom goals and the adoption of personal achievement goals. British Journal of Educational Psychology, 81(4), 680-699. https://doi. org/10.1111/j.2044-8279.2010.02012.x.

Setiawan, E., Juliantine, T., \& Komarudin, K. (2017, 18-19 October). Development creativity students through problem based learning model in physical education in reviewed of adversity quotient. Paper presented at the $2^{\text {nd }}$ International Conference on Sports Science, Health and Physical Education, Universitas Pendidikan Indonesia, Indonesia. https:// doi.org/10.5220/0007066606110613.

Shen, L., Lee, J., Chen, C., \& Zhang, T. (2020). High school adolescents' physical activity and physical fitness: A $3 \times 2$ achievement goal approach. Sustainability, 12(15), 1-9. https://doi.org/10.3390/su12156005.

Soto-Sanz, V., Piqueras, J. A., Rodríguez-Marín, J., Pérez-Vázquez, M. T., RodríguezJiménez, T., Castellví, P., ... \& Alonso, J. (2019). Self-esteem and suicidal behavior in youth: A meta-analysis of longitudinal studies. Psicothema, 31(3), 246-254. https://doi.org/10.7334/ psicothema2018.339.

Sowislo, J. F., \& Orth, U. (2013). Does low selfesteem predict depression and anxiety? A meta-analysis of longitudinal studies. Psychological Bulletin, 139(1), 213-240. https://doi.org/10.1037/a0028931.

Snyder, K.E., \& Linnenbrink-Garcia, L. (2013).A developmental, personcentered approach to exploring multiple motivational pathways in gifted underachievement. 
Educational Psychologist, 48(4), 209228. https://doi.org/10.1080/00461520.2 $\underline{013.835597 .}$.

Snyder, K. E., Malin, J. L., Dent, A. L., \& Linnenbrink-Garcia, L. (2014). The message matters: The role of implicit beliefs about giftedness and failure experiences in academic selfhandicapping. Journal of Educational Psychology, 106(1), 230-241. https://doi. org/10.1037/a0034553.

Török, L., Szabó, Z. P., \& Tóth, L. (2018). A critical review of the literature on academic self-handicapping: theory, manifestations, prevention and measurement. Social Psychology of Education, 21(5), 11751202. https://doi.org/10.1007/s11218018-9460-z.

Urdan, T. (2004). Predictors of academic self-handicapping and achievement: Examining achievement goals, classroom goal structures, and culture. Journal of Educational Psychology, 96(2), 251-264. https://doi.org/10.1037/00220663.96.2.251.

Vílchez, P. C., \& Ruiz, F. J. (2016). Achievement goals in physical education and sport and physical activity in leisure on students from Spain, Costa Rica and Mexico. Journal of Physical Education, 27(1), 1-12. https://doi.org/10.4025/jphyseduc. v27i1.e2701.

Yavuzer, Y. (2015). Investigating the relationship between self-handicapping tendencies, self-esteem and cognitive distortions. Educational Sciences: Theory \& Practice, 15(4), 879-890. https://doi.org/10.12738/ estp.2015.4.2434.

Yazon, A. D., \& Ang-Manaig, K. (2019). Emotional intelligence and occupational stress among Filipino teachers. Universal Journal of Educational Research, 7(11), 2303-2313. https://doi.org/10.13189/ ujer.2019.071108.

Yıldırım, F. B., \& Demir, A. (2020). Selfhandicapping among university students: The role of procrastination, test anxiety, self-esteem, and selfcompassion. Psychological Reports, 123(3), 825-843. $\quad$ https://doi. org/10.1177/0033294118825099.

Zuckerman, M., \& Tsai, F. F. (2005). Costs of self-handicapping. Journal of Personality, 73(2), 411-442. https://doi.org/10.1111/ j.1467-6494.2005.00314.x. 